\title{
Transmission of Coxiella burnetii to Calves from Infected Cows
}

\author{
Miodrag Radinović, Ivana Davidov, Zorana Kovačević, Mihajlo Erdeljan, Marija Pajić \& Annamaria Galfi
}

\begin{abstract}
Background: Coxiella burnetii is the causative agent of a very important disease with zoonotic potential. Infected cows represent risk for spreading of infection to humans and to other animals on farm and also to their offspring. There is possibility for calves from infected cows to be infected nearly after parturition or during intrauterine life. Studies have shown that Coxiella burnetii initially infects the placenta and subsequent spread to the fetus may occur either by haematogenous or by the amniotic-oral route providing congenital infection. The main objective of the present study is to determine the presence of Coxiella burnetii genome in milk serum of infected cows and blood serum of calves.

Materials, Methods \& Results: A total of 200 blood serums from dairy cows were tested for presence of antibodies to Coxiella burnetii and nine of those were found positive. These animals compiled experimental group. From animals in experimental group milk samples during lactation, pregnancy and the postpartum period were collected. Samples were used for performing PCR test for determination of Coxiella burnetii presence in milk serum. On calving of each cow blood samples were taken from calves during first 24 hours after calving, from jugular vein. These blood samples were also used for PCR test to determine the presence of Coxiella burnetii. Milk serum analysis showed presence of Coxiella burnetii genome in serum, indicating on intermittent excretion. During lactation, the excretion of bacteria was greatest in the second stage when $80 \%$ of milk serum samples were positive for Coxiella burnetii. In the colostrums stage, there was a high percentage of Coxiella burnetii excretion through milk (50\% of positive milk serum samples). The lowest percentage of excretion through milk was in the first stage of lactation. Analyzing blood serum samples from calves, taken on first day at calving using PCR method, all serums were positive for presence of Coxiella burnetii genome.

Discussion: In animals, Coxiella burnetii is found in the reproductive system, both uterus and mammary glands, and may cause abortion or infertility. The high prevalence of Coxiella burnetii infection in dairy cattle with reproductive problems showed that these infected cattle play an important role in maintaining the infection and in disseminating of pathogenic agent to environment. The lowest percentage of excretion of Coxiella burnetii was in the first stage of lactation, amounting to $16.6 \%$. With the transition to the next stage of lactation, a striking increase in the percentage of excretion was noticed. In the second stage it was $80 \%$. In the third stage there was decrease to $40.6 \%$. In colostrums stage percentage of excretion through milk was 50\%. Similar results claims that excretion of Coxiella burnetii through milk starts after eight to twelve weeks of lactation in most cows. This period coincides with second stage of lactation as we divide it. Blood serums taken from calves were proven positive on Coxiella burnetii which indicates on intrauterine infection as described in the literature. Intrauterine infection takes place after placenta infection when bacteria penetrate the placenta and contaminate the amniotic fluid and gets aspirated or swallowed by fetus. Besides this, haematogenous spread can also occur.
\end{abstract}

Keywords: Coxiella burnetii, transmission, cow, calves. 


\section{INTRODUCTION}

Coxiella burnetii is the causative agent of $\mathrm{Q}$ fever, zoonosis that is present throughout the world [3]. The most important source for human infection is marked to be domestic animals [12,15]. Q fever mostly passes as a latent disease and the commonest clinical symptoms are abortions and reduced fertility. In addition to these symptoms related to the reproductive tract, occurrence of pneumonia, mastitis and polyarthritis have also been observed [13,18].

The pathogenesis of this disease is characterized with primary replication in the lymph nodes, followed by stage of bacteremia and after that, localization of agent in predilection organs, primarily in mammary gland and uterus in pregnant animals $[11,12]$. Localization of pathogens in the mammary gland is critical for long-term secretion through milk, so the cows can excrete the agents through milk more than a year [7,12]. Presence of bacteria in uterus causes a latent infection that remains localized in the placenta or spreads to the fetus [1]. This situation is characterised by normal offspring that may or may not be congenitally infected and vaginal excretion of organisms during parturition and in the postpartum period. An active infection that may remain limited to the placenta, or may spread to the fetus by the haematogenous or the amniotic-oral route will most likely compromise the fetus and cause abortion, premature delivery, stillbirth and weak offspring and normal but congenitally infected offspring also can be found.

The objective of this work was to explore possibility of intrauterine infection of calves originating from seropositive cows and also to examine excretion of Coxiella burnetii through colostrums and milk.

\section{MATERIALS AND METHODS}

\section{Experimental animals and sample collection}

Serological screening of blood serum samples for antibodies to Coxiella burnetii was performed on a farm with 200 holstein-friesian dairy cows using ELISA method. Commercial ELISA kits (Chekit Q fever $)^{1}$. Based on the results of the ELISA tests, an experimental group of cows, serologically positive for Coxiella burnetii was formed. In total, the experiment included nine dairy cows. The cows were in good body condition and showed no clinical signs of disease. There was only one abortion that occurred during experiment, one cow could not get pregnant and another seven cows gave birth to clinically healthy calves.

From the experimental animals, milk samples during lactation, pregnancy and the postpartum period were collected during regular milking using truetesters. Before taking milk samples teat ends were disinfected using 70\% alcohol. Samples were used for performing PCR test for determination of Coxiella burnetii presence in milk serum. On calving of each cow blood samples were taken from calves during first $24 \mathrm{~h}$ after calving, from jugular vein. These blood samples were also used for PCR test to determine the presence of Coxiella burnetii.

\section{Performing of PCR test}

After arriving in the laboratory, milk samples were placed in an incubator for $24-48 \mathrm{~h}$. Incubation was carried out at a temperature of $38^{\circ} \mathrm{C}$ to form coagulum and milk serum.

Blood samples were stored in room temperature for $48 \mathrm{~h}$ to segregate the serum. After that serum was pour off and stored in freezer until performing PCR test.

The PCR method was used to determine the presence of Coxiella burnetii genome in milk and blood serum samples. For serum samples, a 200- $\mu \mathrm{L}$ of sample volume was used. Cells were lysed with proteinase $\mathrm{K}$ (final concentration, $200 \mu \mathrm{g} / \mathrm{mL}$ ) at $56^{\circ} \mathrm{C}$ overnight. DNA was prepared with a Prep-A-Gene purification $\mathrm{kit}^{2}$ by using $10 \mu \mathrm{L}$ of silica matrix. DNA was eluted from the silica matrix by adding $100 \mu \mathrm{L}$ of Prep-A-Gene elution buffer. To increase the yield, DNA was eluted at $56^{\circ} \mathrm{C}$ for $5 \mathrm{~min}$ and centrifuged again. One microliter of supernatant containing DNA was used for amplification. Used primers were as followed:

Trans 1: 5'-TGGTATTCTTGCCGATGAC-3'; Trans 2: 5'-GATCGTAACTGCTTAAT AAACCG-3'.

\section{RESULTS}

Processing of blood serum samples from 200 cows on tested farm by ELISA test has shown presence of antibodies for Coxiella burnetii in 9 cows. These animals accounted for $4.5 \%$ of total herd.

From seropositive cows, 65 samples of milk serum were collected by successive lactation stages. The results of the analysis of these samples using the 
PCR method are shown in Table 1. During lactation, the excretion of bacteria was greatest in the second stage when $80 \%$ of milk serum samples were positive for Coxiella burnetii. In the colostrums stage, there was a high percentage of Coxiella burnetii excretion through milk (50\% of positive milk serum samples).
The lowest percentage of excretion through milk was in the first stage of lactation (Table 1).

Analyzing blood serum samples from calves, taken on first day at calving using PCR method, all serums were positive for presence of Coxiella burnetii genome (Table 2).

Table 1. Excretion of Coxiella burnetii through milk in different lactation stages.

\begin{tabular}{ccccc}
\hline Stage of lactation & $\begin{array}{c}\text { Colostral stage } \\
\text { First 10 days }\end{array}$ & $\begin{array}{c}\text { First stage } \\
10-60 \text { days }\end{array}$ & $\begin{array}{c}\text { Second stage } \\
60-180 \text { days }\end{array}$ & $\begin{array}{c}\text { Third stage } \\
\text { Over 180 days }\end{array}$ \\
\hline Number of samples & 4 & 8 & 20 & 33 \\
C. burnetii & $50 \%$ & $16.6 \%$ & $80 \%$ & $40.6 \%$ \\
\hline
\end{tabular}

Table 2. Presence of Coxiella burnetii genome in blood serum of calves.

\begin{tabular}{cccccccc}
\hline ID number of calf & 6956 & 6989 & 2729 & 6952 & 6981 & 2710 & 2721 \\
\hline C. burnetii & positive & positive & positive & positive & positive & positive & positive \\
\hline
\end{tabular}

\section{DISCUSSION}

Q fever disease caused by Coxiella burnetii, is an important zoonosis found worldwide. In humans, it causes a variety of diseases such as acute flu-like illness, pneumonia, hepatitis, and chronic endocarditis [3,4]. In animals, Coxiella burnetii is found in the reproductive system, both uterus and mammary glands, and may cause abortion or infertility $[19,20]$. The high prevalence of Coxiella burnetii infection in dairy cattle with reproductive problems showed that these infected cattle play an important role in maintaining the infection and in disseminating of pathogenic agent to environment. Thus, such excretions (milk, colostrums, urine, and birth fluid) are considered to be potential sources of infection in animals and humans via inhalation of infectious aerosols or airborne dust [13,21].

According to our results (Table 1), the lowest percentage of excretion of Coxiella burnetii was in the first stage of lactation, amounting to $16.6 \%$. With the transition to the next stage of lactation, a striking increase in the percentage of excretion was noticed. In the second stage it was $80 \%$. In the third stage there was decrease to $40.6 \%$. In colostrums stage percentage of excretion through milk was $50 \%$. Similar results were published by Rodolakis et al. [16] who claim that excretion of Coxiella burnetii through milk starts after eight to twelve weeks of lactation in most cows. This period coincides with second stage of lactation as we divide it. Also shedding of Coxiella burnetii through milk is often associated with presence of subclinical mastitis [4].

Blood serums taken from calves were proven positive on Coxiella burnetii (Table 2) this indicates on intrauterine infection as described by Agerholm [1]. Intrauterine infection is aftermath of placenta infection, which can remain confined to placenta or bacteria can penetrate the placenta and contaminate the amniotic fluid so after aspirated or swallowed by fetus [14]. Besides this, haematogenous spread through umbilical vessels can also occur leading to finding of bacteria in multiple tissues. Fetus can produce antibodies to Coxiella burnetii, so IgM antibodies can be found in fetal blood serum, which can be helpful in assessment of significance of Coxiella burnetii as cause of abortion.

Presence of Coxiella burnetii genome in blood serum is consequence of lysis of infected cells by antibody-dependent system. So bacteria became free in blood serum [7].

\section{CONCLUSION}

Dairy cows represent an important reservoir of Coxiella burnetii, spreading the agent into environment, in food chain and to their offspring via intrauterine infection. 


\section{MANUFACTURERS}

${ }^{1}$ IDEXX Laboratories Inc. Westbrook, ME, USA.

${ }^{2}$ Bio-Rad Laboratories GmbH. Munich, Germany.

Funding. This research was financed by the Ministry of Science and Technological Development, Republic of Serbia, [Grant number TR 31034].
Ethical approval. All procedures were approved by the decision, number 01-153/7-3, of the Ethical Committee of the University of Novi Sad, in order to safeguard the welfare of experimental animals.

Declaration of interest. The authors report no conflicts of interest. The authors alone are responsible for the content and writing of the paper.

\section{REFERENCES}

1 Agerholm J.S. 2013. Coxiella burnetii associated reproductive disorders in domestic animals-a critical review. Acta Veterinaria Scandinavica. 55(1): 13. doi: 10.1186/1751-0147-55-13.

2 Arricau-Bouvery N. \& Rodolakis A. 2005. Is Q fever an emerging or re-emerging zoonosis. Veterinary Research. 36(3): 327-349.

3 Barlow J., Rauch B., Welcome F., Kim S.G., Dubovi E. \& Schukken Y. 2008. Association between Coxiella burnetii shedding in milk and subclinical mastitis in dairy cattle. Veterinary Research. 39(3): 23. doi: 10.1051/vetres:2007060.

4 Behymer D.E., Biberstein E.L., Riemann H.P., Franti C.E., Sawyer M., Ruppanner R. \& Crenshaw G.L. 1976. Q fever (Coxiella burnetii) investigations in dairy cattle: challenge of immunity after vaccination. American Journal of Veterinary Research. 37: 631-634.

5 Boboš S. \& Vidić B. 2005. Mlečna žlezda preživara- morfologija- patologija- terapija. Novi Sad: Poljoprivredni fakultet- Departman za veterinarsku medicinu, Naučni istitut za veterinarstvo „Novi Sad“.

6 Cerf O. \& Condron R. 2006. Coxiella burnetii and milk pasteurization: an early application of the precautionary principle? Epidemiology and Infection. 134(5): 946-951.

7 Jerrells T.R. 1988. Mechanisms of immunity to Rickettsia species and Coxiella burnetii. In: Walker D.H. (Ed). The Biology of the Rickettsiae. vol.II. Boca Raton: CRC Press, pp.79-100.

8 Kirkan S., Kaya O., Tekbiyik S. \& Parin U. 2008. Detection of Coxiella burnetii in cattle by PCR. Turkish Journal of Veterinary and Animal Sciences. 32(3): 215-220.

9 Lorenz H., Jager C., Willems H. \& Baljer G. 1998. PCR detection of Coxiella burnetii from different clinical specimens, especially bovine milk, on the basis of DNA preparation with a silica matrix. Applied and Environmental Microbiology. 64: 4234-4237.

10 Marrie T.J. \& Raoult D. 2002. Update on Q fever, including Q fever endocarditis. Current Clinical Topics in Infectious Diseases. 22: 97-124.

11 Maurin M. \& Raoult D. 1999. Q fever. Clinical Microbiology Reviews. 12: 518-553

12 McQuiston J.H., Childs J.E. \& Thompson H.A. 2002. Q Fever. Journal of American Veterinary Medicine Association. 221(6): 796-799.

13 Muskens J., van Engelen E., van Maanen C., Bartels C. \& Lam T.J. 2011. Prevalence of Coxiella burnetii infection in Dutch dairy herds based on testing bulk tank milk and individual samples by PCR and ELISA. Veterinary Record. 168(3): 79. doi: 10.1136/vr.c6106.

14 Ozkaraca M., Ceribasi S., Ceribasi A.O., Kilic A., Altun S., Comakli S. \& Ongor H. 2016. Determination of Coxiella burnetii in bovine foetuses using PCR and immunohistochemistry. Veterinarny Medicina. 61(8): 421-427.

15 Radinović M., Boboš S., Pajić M., Vidić B., Rašić Z., Davidov I. \& Špegar R. 2011. Blood count and number of somatic cells in milk of cows infected with Coxiella burnetii. Veterinarski glasnik. 65(5-6): 367-374.

16 Rodolakis A., Berri M., Héchard C., Caudron C., Souriau A., Bodier C.C., Blanchard B., Camuset P., Devillechaise P., Natorp J.C., Vadet J.P. \& Arricau-Bouvery N. 2007. Comparison of Coxiella burnetii shedding in milk of dairy bovine, caprine, and ovine herds. Journal of Dairy Science. 90(12): 5352-5360.

17 E., Berri M., Durand B., Dufour P., Prigent M., Delcroix T., Touratier A. \& Rodolakis A. 2009. Coxiella burnetii shedding routes and antibody response after outbreaks of $\mathrm{Q}$ fever-induced abortion in dairy goat herds. Applied and Environmental Microbiology. 75(2): 428-433.

18 To H., Htwe K.K., Kako N., Kim H.J., Yamaguchi T., Fukushi H. \& Hirai K. 1998. Prevalence of Coxiella burnetii infection in dairy cattle with reproductive disorders. Journal of Veterinary Medical Science. 60(7): 859-861. 
19 van Der Hoek W., Dijkstra F., Schimmer B., Schneeberger P.M., Vellena P., Wijkmans C., ter Schegget R., Hackert V. \& van Duynhoven Y. 2010. Q fever in the Netherlands: an update on the epidemiology and control masures. Euro Surveillence. 15: 12. pii: 19520.

20 Vidić B., Boboš S., Savić S. \& Prica N. 2008. Findings of Coxiella burnetii in milk and her significance for human infection. Contemporary agriculture. 57(3-4): 208-215.

21 Woldehiwet Z. 2004. Q fever (coxiellosis): epidemiology and pathogenesis. Research in Veterinary Science. 77(2): 93-100. 